\title{
The Effects on Cell Adhesion of Fibronectin and Gelatin in a Serum-Free, Bovine Serum Albumin Medium
}

\author{
Mikio Kan ${ }^{1}$, Yoshiki Minamoto ${ }^{1}$, Sachiko Sunami ${ }^{1}$, Isao Yamane $^{1}$ and \\ Makoto Umeda ${ }^{2}$ \\ ${ }^{1}$ Cell biology Division, Research Institute for Tuberculosis and Cancer, Tohoku \\ University, Sendai 980, Japan and ${ }^{2}$ Tissue Culture Laboratory, Yokohama City \\ University School of Medicine, Urafune-cho, Minamiku, Yokohama 232, Japan
}

\begin{abstract}
Macromolecules which eliminate the effects of bovine serum albumin (BSA) to inhibit cell adhesion, were investigated using serum-free medium supplemented with $5 \mathrm{~g} / 1$ of BSA. Fibronectin (FN) produces adhesion in various types of cells-BHK-21, TE-1, FL, HeLa-S ${ }_{3}$ and human diploid fibroblasts, while as does gelatin in fibroblasts and TE-1 cells. These two types which adhered to gelatin-coated dishes secreted sufficient amounts of cellular FN into the cultured medium to allow such adhesion. The dual effects of both FN and gelatin were exhibited only when added prior to BSA. This indicates that further adsorption of either FN or gelatin is inhibited when BSA has already been adsorbed on the substratum. FN may also act as an adhesive bridge between cells and gelatin-coated or non-treated dishes.
\end{abstract}

Serum contains a factor which causes cultured mammalian cells to adhere to plastic substrata $(4,6)$, which in turn is conditioned by this serum-derived factor. For this reason, adhesion factors have been studied mainly in serum-free cultures $(2,12)$. BSA has been reported to promote growth in Yoshida sarcoma cells and human lymphoblastoid cells in serum-free suspension cultures (19). However, BSA inhibits the adhesion of cells growing on the substratum of a culture $(5,7)$. Therefore, adhesion factors which are believed to eliminate the inhibitory effects of BSA were examined here in order to study its growth-promoting action in anchorage-dependent cells.

Fibronectin and gelatin were effective in attaching human diploid fibroblasts and TE-1 cells to the plastic substratum, whereas only fibronectin was as effective in the BHK, HeLa and FL cell lines. The differences in the mechanism between these two macromolecules were also examined.

\section{MATERIALS AND METHODS}

Cells and cell culture. Human diploid fibroblasts were obtained from embryo lungs as described previously $(10,17)$, and were maintained at a $1: 2$ dilution in plastic petri dishes

Abbreviations used: BSA, bovine serum albumin; CS, Calf serum; FBS, fetal bovine serum; FN, fibronectin; HEL, human embryonic lung fibroblasts (or human diploid fibroblasts); HEPES, N-2-hydroxyethylpiperazine- $N^{\prime}$-2-ethanesulfonic acid; MEM, Eagle's minimum essential medium. 
(Lux Co., $60 \mathrm{~mm}$ in diameter). They were grown routinely in a modified Eagle's minimum essential medium (modified MEM) (18) supplemented with 10\% fetal bovine serum (FBS). The cell population doubling number achieved through in vitro senescence was about 80 , and experiments were made on cells at the less than 40 level. BHK-21 (a baby hamster kidney cell line), HeLa-S3 (a human cervical carcinoma cell line), and FL (a human amnion cell line) were growth in modified MEM with 10\% calf serum (CS). TE-1 (a human esophageal carcinoma) was grown in the same medium with $10 \%$ FBS (14). Cells at exponential growth were harvested with $0.01 \%$ trypsin $(2 \times$ crystalline, Miles Co. $), 0.02 \%$ EDTA in $\mathrm{Ca}^{++}$, $\mathrm{Mg}^{++}$-free PBS.

Cell attachment assay. To determine cell attachment, cells $\left(4-5 \times 10^{4}\right.$ cells/dish) were plated in plastic petri dishes, $35 \mathrm{~mm}$, in diameter with $1.5 \mathrm{ml}$ of adhesion medium (modified MEM supplemented with $14 \mathrm{mM}$ HEPES, $\mathrm{pH}$ 7.3). Prior to the addition of the cells, the dishes were coated with various serum fractions or connective tissue-derived macromolecules. Following the addition of the cells, BSA solution was added to the dishes at a concentration of $5 \mathrm{~g} / \mathrm{l}$. After incubation for $3 \mathrm{~h}$ at $37^{\circ} \mathrm{C}$ in air plus $5 \% \mathrm{CO}_{2}$, floating cells and attached cells were counted separately. The attached cells were counted after trypsinization. Cell attachment $(\%)$ was calculated from the ratio of total cells (floating cells plus attached cells) to attached cells.

Pretreatment and conditioning of the substrata. Pretreated substrata were prepared by the addition of PBS with several macromolecules to the dishes and incubated for $30 \mathrm{~min}$. at room temperature. They were then rinsed twice with distilled water.

Conditioned substrata were prepared by incubating selected cells in serum-free RITC 80-7 medium $(10,17)$ in air plus $5 \% \mathrm{CO}_{2}$ at $37^{\circ} \mathrm{C}$ for $24 \mathrm{~h}$. At the end of an incubation period, the substrata were treated for $10 \mathrm{~min}$, with $1 \%$ triton $\mathrm{X}-100$ in distilled water at room temperature (5), and then rinsed once with distilled water.

Chemicals. Fibronectin (cold insoluble globulin) was prepared from human blood plasma by gelatin-affinity column chromatography as described by Engvall and Ruoslahti (3). $\alpha_{2}$-Macroglobulin from human plasma came from Osaka University. Other chemicals were obtained from the following sources: Cohn's serum fractions (Fraction I-V) from Miles Laboratories (Enkhart, U.S.A.); gelatin (Swin skin type 1), $a_{1}$-antitrypsin and HEPES from Sigma Chemicals (St. Louis, U.S.A.); hyaluronic acid and chondroitin sulfate from Seikagaku Kogyo Co. (Tokyo); Heparin from NOVO (Denmark); Collagen (K-BED) from Kureha Chemical Co. (Tokyo); Triton X-100 from Wako Pure Chemicals (Osaka); fetal bovine serum and calf serum from Flow Laboratories (N.S.W. Australia).

Purified fibronectin was dialyzed in $\mathrm{Ca}^{++}$, $\mathrm{Mg}^{++}$-free PBS containing a double concentration of $\mathrm{NaCl}$ and adjusted to a $\mathrm{pH}$ of 11 with $\mathrm{NaOH}$. Dialyzed fibronectin was filtersterilized and stored at concentrations of $80-100 \mu \mathrm{g} / \mathrm{ml}$ at $-80^{\circ} \mathrm{C}$. Gelatin was mixed in $\mathrm{Ca}^{++}$-, $\mathrm{Mg}^{++}$-free PBS at a $1 \%$ concentration and dissolved at $56^{\circ} \mathrm{C}$. It was then filter-sterilized and stored at $4^{\circ} \mathrm{C}$.

\section{RESULTS}

The effects on cell adhesion of substrata coated with several serum fractions. Serumfree culture medium, RITC 80-7, has recently been developed and the long-term culturing of several types of attached cells including human diploid fibroblasts (HEL) has been attempted using media supplemented with BSA $(5 \mathrm{~g} / 1)(10,17)$. However, the BSA inhibited cell adhesion on the substratum. Table 1 shows the extent to which BHK cells adhered to dishes coated with eight macromolecules in BSA supplemented 


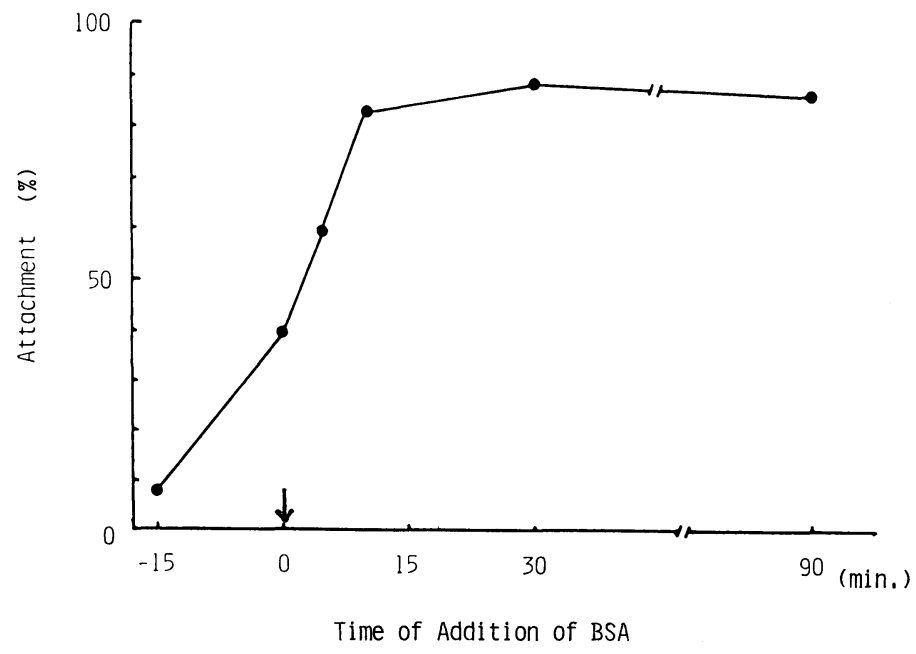

Fig. 1. The effects of BSA in the presence of FN for adhesion by BHK cells. Twenty $\mu \mathrm{g} / \mathrm{dish} \mathrm{FN}$ was added to dishes containing $1.5 \mathrm{ml}$ each of medium. BSA to a final concentration of $5 \mathrm{~g} / 1$ and BHK cells $\left(4 \times 10^{4}\right.$ cells/dish) were added to the dishes at indicated times. Values are the means of duplicate determinations. Arrow indicates time of addition of FN.

adhesion medium. Cohn's serum fractions II, III, IV. V, $\alpha_{1}$-antitrypsin and $\alpha_{2}$-macroglobulin did not reverse the effects of BSA on cell adhesion. In contrast, excellent adhesion was found when the coating was of either Cohn's fraction I or $10 \%$ serum. Similar results were obtained for HEL cells. Fraction I and serum contain fibronectin (FN) $(9,16)$, and external FN promotes BHK cell adhesion (8). Although FN (20 $\mu \mathrm{g} / \mathrm{ml}$ ) added prior to BSA clearly reversed the latter's effects, FN added after BSA did not (Fig. 1).

FN and gelatin adhesion activity. To examine cell adhesion activity of FN purified from human plasma, BHK-21 and HEL cells were used. In the absence of FN, both

TABLE 1. THE EFFECTS OF COATING DISHES WITH EIGHT MACROMOLECULES IN TERMS OF BHK CELL ADHESION

\begin{tabular}{cc}
\hline Treatment with & Attachment \% \\
\hline Non-treatment & 12.3 \\
Cohn's Fr. I & 52.3 \\
II & 4.2 \\
III & 4.2 \\
IV & 3.1 \\
V & 3.1 \\
$a_{1}$-Antitrypsin & 22.3 \\
$a_{2}$-Macroglobulin & 16.9 \\
Serum & 43.4
\end{tabular}

Dishes were treated with the each macromobelules indicated at concentrations of $10 \mathrm{mg} / \mathrm{l}$ or with $10 \%$ FBS. Values are the means of triplicate determinations. 


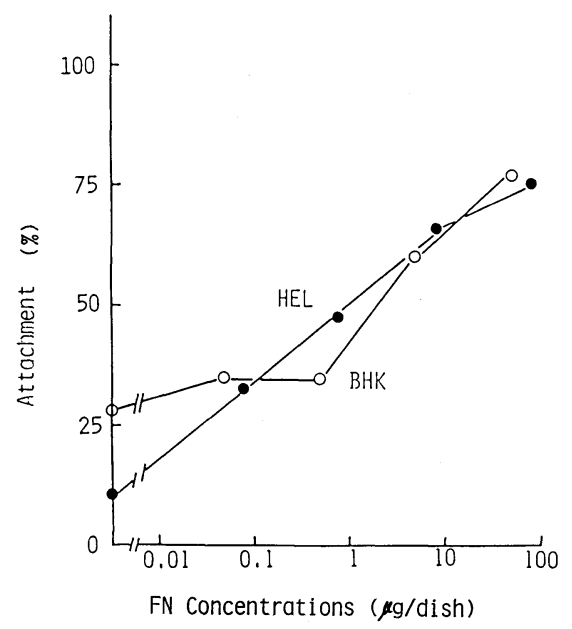

Fig. 2. The effects of FN on adhesion by BHK and HEL cells. Cells $\left(4 \times 10^{4}\right.$ cells $/$ dish $)$ were plated on $1.5 \mathrm{ml}$ adhesion medium after the addition of the indicated concentrations of FN. Then, $5 \mathrm{~g} / 1$ of BSA was added. Values are the means of duplicate determinations.

TABLE 2. THE EFFECTS OF COATING DISHES WITH CONNECTIVE TISSUE-DERIVED MACROMOLECULES IN TERMS OF HEL CELL ADHESION

\begin{tabular}{lc}
\hline Treatment with & Attachment \% \\
\hline Non-treatment & $18 \pm 0.8$ \\
Gelatin & $77 \pm 5$ \\
Hyaluronic acid & $40 \pm 5$ \\
Chondroitin sulfate & $32 \pm 1$ \\
Heparin & $32 \pm 2$ \\
Fibronectin & $69 \pm 3$
\end{tabular}

Dishes were treated $0.3 \mathrm{mg} / \mathrm{ml}$ gelatin, hyarulonic acid, chondroitin sulfate and heparin indicated or with $20 \mu \mathrm{g} / \mathrm{ml}$ of $\mathrm{FN}$. Values are the means $( \pm \mathrm{SD})$ of triplicate determinations.

types remained round and floated in the BSA medium. In the presence of FN, the cells attached and spread thickly over the substratum. Attachment ratios of the two cell types at varying FN concentrations in serum-free medium are shown in Fig. 2. The FN dosage for half maximum effect was $0.3 \mu \mathrm{g} / \mathrm{cm}^{2}$, and the FN concentration for complete cell adhesion was approximately $0.5 \mu \mathrm{g} / \mathrm{cm}^{2}$. Effective FN dosage level did not change for the various cell lines tested (data not shown). Using the above procedure, the effects of hyaluronic acid, chondroitin sulfate, heparin and gelatin were tested. Gelatin is known to bind to $\mathrm{FN}(3,16)$. None of the substances were effective in attaching BHK cells, but gelatin improved HEL cell attachment (Table 2). Gelatin dosage for half maximum effect was $5 \mu \mathrm{g} / \mathrm{cm}^{2}$ and that required for maximum cell adhesion was approximately $20 \mu \mathrm{g} / \mathrm{cm}^{2}$ (Fig. 3), but it also lost much of its effects when added after BSA.

The Differences between $F N$ and gelatin in cell adhesion. To compare the differences in cell adhesion between FN and gelatin, attachment efficiency to dishes coated with 


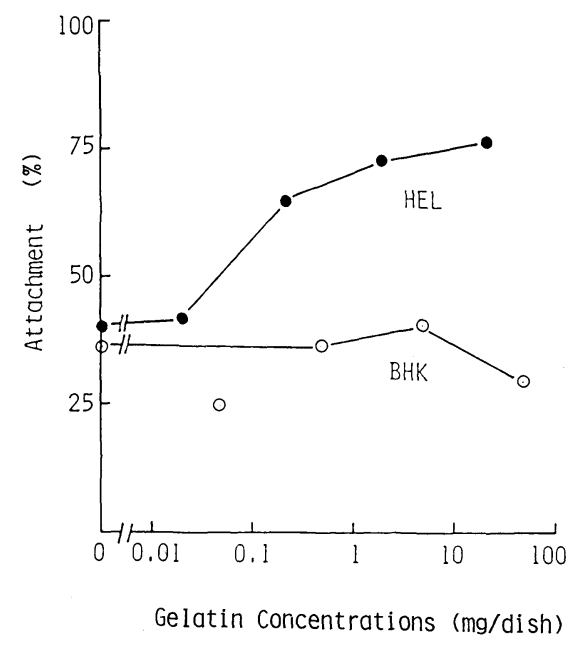

Fig. 3. The effects of gelatin on adhesion by BHK and HEL cells. Cells $\left(4 \times 10^{4}\right.$ cells/dish) were plated on $1.5 \mathrm{ml}$ adhesion medium after the addition of the indicated concentrations of gelatin. Then, $5 \mathrm{~g} / 1$ BSA was added. Values are the means of duplicate determinations.

TABLE 3. THE EFFECTS OF FN AND GELATIN ON THE ADHESION OF VARIOUS CELL TYPES

\begin{tabular}{lccc}
\hline & \multicolumn{3}{c}{ Attachment $\%$} \\
\cline { 2 - 4 } Cell line & FN & Gelatin & Non-treatment \\
\hline HEL & 68.3 & 72.9 & 20.0 \\
BHK & 70.8 & 23.6 & 37.8 \\
TE-1 & 68.3 & 66.3 & 39.1 \\
HeLa & 90.6 & 51.8 & 5.6 \\
FL & 61.8 & 34.5 & 35.8
\end{tabular}

Dishes were treated with either $20 \mu \mathrm{g} /$ dish of FN or $200 \mu \mathrm{g} /$ dish of gelatin. Values are the means of duplicate determinations.

TABLE 4. THE EFFECT OF CONDITIONING WITH VARIOUS CELL TYPES IN TERMS OF BHK CELL ADHESION

\begin{tabular}{lcc}
\hline \multirow{2}{*}{$\begin{array}{l}\text { Cell line or Forms of } \\
\text { treatment }\end{array}$} & \multicolumn{2}{c}{ Attachment $\%$} \\
\cline { 2 - 3 } Non-treatment & Experiment 1 & Experiment 2 \\
HEL & 15.0 & 2.6 \\
BHK & 66.3 & 73.5 \\
TE-1 & & 6.8 \\
HeLa & 83.8 & 7.4 \\
FL & 13.3 & 25.7 \\
Fibronectin & & 64.3 \\
\hline
\end{tabular}

Dishes were conditioned with various cell types $\left(5 \times 10^{4}\right.$ cells $)$ in RITC $80-7$ Serum-free medium for $24 \mathrm{~h}$. Values are the means of duplicate determinations. 
TABLE 5. THE EFFECTS OF COATING DISHES WITH COLLAGEN AND GELTIN IN TERMS OF BHK AND HEL CELL ADHESION

\begin{tabular}{ccccc}
\hline \multirow{2}{*}{ Cell line } & \multicolumn{4}{c}{ Attachment \% } \\
\cline { 2 - 5 } & FN & Gelatin & Collagen & Non-treatment \\
\hline HEL & 74.5 & 72.4 & 65.5 & 22.4 \\
BHK & 50.0 & 24.0 & 10.2 & 17.0 \\
\hline
\end{tabular}

Dishes were treated with $2-3 \mathrm{mg} / \mathrm{ml}$ of collagen, $200 \mu \mathrm{g} / \mathrm{dish}$ of gellatin or $20 \mu \mathrm{g} / \mathrm{dish}$ of FN as described. Values are the means of duplicate determinations.

each was examined using BSA supplemented adhesion medium and several cell lines (Table 3). All lines adhered to the FN-coated dishes, but only two of the six cell lines adhered to those coated with gelatin. When dishes were untreated, adhesion was poor in all cases. Since fibroblasts produce and release cellular FN into culture media $(5,16)$, the amount which had been secreted was assayed by the method of Grinnell (5). Table 4 shows the extent of BHK cell attachment after the cells had been incubated for $24 \mathrm{~h}$ in a medium of serum-free RITC 80-7. In this case, only HEL and TE-1 cells which adhere to gelatin-coated dishes, produced sufficient amounts of FN. Gelatin is therefore effective only when cells produce cellular FN and the released FN fixes to it. Collagen behaved in a manner similar to gelatin (Table 5).

\section{DISCUSSION}

Human diploid fibroblasts do not require specific factors in order to adhere to plastic substratum because they secrete sufficient amounts of FN into the medium (13). However in serum-free, BSA medium, FN must be added prior to BSA. Furthermore, there are inhibitory effects not only in albumin but also in other serum proteins (fractions). This gives the following interpretation: when BSA or other serum proteins are coated on substratum, further adsorption of $\mathrm{FN}$ is prevented. Most proteins are adsorbed onto substrata whose physicochemical properties may cause them to change their conformations (1). Therefore, cell adhesion may be inhibited by proteins which have pre-adsorped and covered available adhesion sites.

The findings here have demonstrated that HEL cells attach and spread on gelatincoated substrata in a serum-free, BSA medium without FN. On the other hand, there was only slight attachment and no spreading at all of BHK cells unless FN was added to the medium. The difference between HEL cells and BHK cells can be accounted for by the fact that the HEL cells themselves secrete FN while the BHK cells do not. The simplest interpretation is that HEL cells adhered to the gelatin using their own cellular FN as an adhesive bridge. This is consistent with the fact that FN binds specifically to gelatin $(3,16)$. In spite of the production of what should be sufficient amounts of cellular FN, HEL and TE-1 cells did not adhere to non-treated dishes. This is because BSA adsorbed prior to FN secretion and inhibited the latter's subsequent adsorption. This indicates that FN cannot bind to BSA and BSA cannot bind to gelatin. The above substances are able, however, to bind themselves to non-treated substrata. The interaction BHK and HEL cells with gelatin and FN has been reported by Grinnell and Minter (8). They found that BHK cells do not interact directly with 
gelatin coated substrata in contrast to fibroblasts. The present findings are consistent with this. On the other hand, it has been reported that cell adhesion on collagen surfaces is mediated by serum FN $(11,15)$. Here, it has been shown that collagen behaves like gelatin in regard to cell adhesion (Table 5), which supports FN's role as an adhesive bridge between cells and gelatin, because gelatin is a denaturated from of collagen.

When BSA, and FN or gelatin were added simultaneously, attachment activity decreased (Fig. 1). Whole serum was ineffective in BHK cell adhesion when compared with $10 \%$ serum (data not shown). The FN concentration required for complete cell adhesion $\left(0.5 \mu \mathrm{g} / \mathrm{cm}^{2}\right)$ was about equivalent to that of $0.5 \%$ serum $(1.5 \mathrm{ml} / 35 \mathrm{~mm} \mathrm{dish})$. In serum-supplemented medium, it is believed that $\mathrm{FN}$, and albumin or other serum proteins are compete with each other.

Acknowledgements. The authors wish to express their appreciation to Dr. Tetsuro Nishihira of the Department of surgery, Tohoku University School of Medicine for a gift of the TE-1 cell line, and to Dr. Setsuro Fujii of Osaka University for $\alpha_{2}$-Macroglobulin.

\section{REFERENCES}

1. Baier, R.E., G.I. Loeb and G.T. Wallace. Role of an artificial boundary in modifying blood proteins. Fed. Proc. 30, 1523-1538, 1971

2. Bottenstein, J.E. and G.H. Sato. Fibronectin and polylysine requirements for proliferation of neuroblastoma cells in defined medium. Exp. Cell Res. 129, 361-366, 1980

3. Engvall, E. and E. Ruoslahti. Binding of soluble form of fibroblast surface protein, fibronectin, to collagen. Int. J. Cancer. 20, 1-5, 1977

4. Grinnell, F. The serum dependence of baby hamster kidney cell attachment to a substratum. Exp. Cell Res. 97, 265-274, 1976

5. Grinnell, F. and M.K. Feld. Initial adhesion of human fibroblasts in serum-free medium: possible role of secreted fibronectin. Cell 17, 117-129, 1979

6. Grinnell, F. and D.G. Hays. Cell adhesion and spreading factor similarity to cold insoluble globulin in human serum. Exp. Cell Res. 115, 221-229, 1978

7. Grinnell, F., D.G. Hays and D. Minter. Cell adhesion and spreading factor, partial purification and properties. Exp. Cell Res. 110, 175-190, 1977

8. Grinnell, F. and D. Minter. Attachment and spreading of baby hamster kidney cells to collagen substrate: effects of cold-insoluble globulin. Proc. Natl. Acad. Sci. U.S.A. 75, 44084412, 1978

9. HeIde, K., H. HAUPT and H.G. SCHWICK. Plasma protein fractionation in the plasma proteins Vol. 3. ed. F.W. Putnam. Academic Press, New York, pp. 545-586, 1977

10. KAN, M. and I. YAMANE. In vitro proliferation and the lifespan of human diploid fibroblasts in serum-free BSA-containing medium. J. Cell Physiol. 111, 155-162, 1982

11. KLEBE, R.J. Isolation of a collagen-dependent cell attachment factor. Nature 250, 248-251, 1974

12. McKeehan, W.L. and R.G. Ham. Stimulation of clonal growth of normal fibroblasts with substrata coated with basic polymers. J. Cell Biol. 71, 727-734, 1976

13. Millis, A.J.T. and M. Hoyle. Fibroblast-conditioned medium contains cell surface proteins required for cell attachment and spreading. Nature 271, 668-669, 1978

14. Nishihira, T., M. Kasai, S. Mori, T. Watanabe, Y. Kuriya, M. Suda, M. Kitamura, K. Hirayama, T. Akaishi and T. Sasaki. Characteristics of two cell lines (TE-1 and TE-2) derived from human squamous cell carcinama of the esophagus. Gann. 70, 575-584, 1979

15. Pearlilein, E. Plasma membrane glycoprotein which mediates adhesion of fibroblasts to collagen. Nature 262, 497-500, 1976

16. Yamada, K.M. and K. Olden. Fibronectins-adhesive glycoproteins of cell surface and blood. Nature 275, 179-184, 1978 
17. Yamane, I., M. Kan, H. Hoshi and Y. Minamoto. Primary culture of human diploid cells and its long-term transfer in a serum-free medium. Exp. Cell Res. 134, 470-474, 1981

18. Yamane, I., Y. Matsuya and K. Jimbo. An autoclavable powdered culture medium for mammalian cells. Proc. Soc. Exp. Biol. Med. 127, 335-336, 1968

19. Yamane, I., O. Murakami and M. Kato. Serum-free culture of various mammalian cells and the role of bovine albumin. Cell Struct. Funct. 1, 279-284, 1976

(Received for publication, July 22, 1982) 